\title{
本菲・横手間の第三紀 層
}

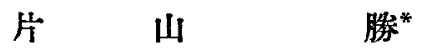

I. $\mathscr{I r}$

II. 地質概要

III. 地質㷣論

A. 西 部.

\author{
目
}

片

次

B. 中 部

C. 東 部.

IV. 装 約

\section{1. 序}

上林教授並に大塚助敎授の御指導のるとに行ひをる昭和 14 年度東北第三

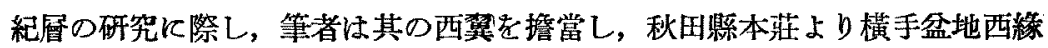
て至るまでの第三紀層を調查した。然し短時日の䈆其の調査は主として所謂 綠色凝灰岩層に限られ, 本莊, 老方, 大森を結ぶ線に沿つて南北約 2 里幅の 範圍である。此の地方全般の地質に關しては既に村山賢一技師の 7 萬 5 千分 の1本莊圖幅並に說明畫（商工省地質調查所發行）があり，古生物學では大 菻助教授の貴重なる御研究があつて，淺學の筆者に注别段附加報告するもの は無へのであるが, 此の調查に當り中央部及び東翼を擔當せられた井尻及び 藏田兩學士の研究之照合し, 東北第三紀層の東西方向の關係追究の赤, 又特 飞所謂綠色凝灰岩覻の解析研究の一助とるなればと思ひ敢て御報告する次第 でする。

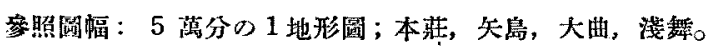

7 萬 5 千分の 1 地質圖；本莊圖幅。

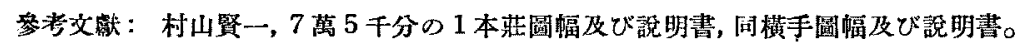
大塚彌之助, 秋时縣由利郡の高㖽川㠜灰岩層, 地質學雜誌, 第 43 卷, 昭和 11 年。

\section{II. 地 質 概 要}

筆者の調查は橫手盆地西線を限つて南北に縱走する山地を略東西に横切る 高瀨川及び㮖跬鐵道東線に沿つて行つたのであつて, 岩石露出は此の幹線に

* 地筫調查所技師 
沿つて㥛めて良好であるが之を離れると餘り良好でない。 調査區域の地質は總て綠色凝灰岩層以後の地詹より成り，其の基盤注露出 してみない。西方本莊を中心とする低地乃至丘陵地は女川珪筫頁岩層より鮹 川砂岩層に至る上部層より成り，概略南北の走向で西へ緩科する單斜構造を 示してわる。山地に入ると大部分法綠色凝灰岩層より成つてをり，之等兩者 は南北に走る斷層に依つて境されてわる。ていに綠色凝灰岩層己呼んだが, 7

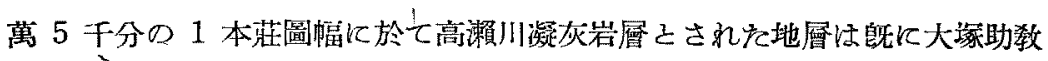
授が提唱されを如く，所謂院內統に相當する下部層と，男鹿島統下部即ち臺 島階に對比される上部層己に區分される。以下前者を高瀨川㠜灰岩層、後者 を須鄉田層己呼ぶ。而して爾者つ構造泟極めて緩漫な波狀褶曲をなし，大觀

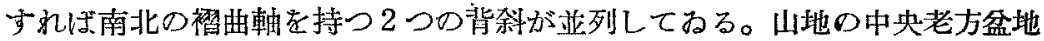

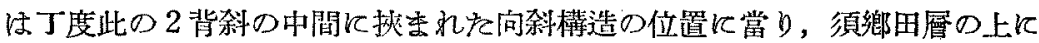
整合的に重る珪質頁岩層が北方より續いて露出してねる。高瀨川㠜灰岩層の 東限は南北の斷層を境こして東方に綬科する珪質頁岩，黑色貣岩雨層が山地 東核に露出してるる。

\section{III. 地 質 詳 論}

以下高瀨川凝灰岩層及び須郷田層を主題己L, 說明の便宜上西方背科, 中 央向科, 束方背斜の順序に區別して詳述して行く。

\section{A. 西 部}

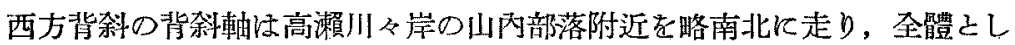
て南に沈降する傾向を示してるる。

東 露 山內上り老方に至る川沿ひには各所に石英粗面岩, 玄武岩, 紫蘇輝 石安山岩, 複輝石安山岩等の多數の小岩脈が露出してるるが, 之等を除外し て高瀨川凝灰岩層及び須郷田層の岩質，層序區分等を模式的に圖示すれば第 1 圖の如くになる。即ち高瀨川凝灰岩層は次の 2 帶に區分し得ら水，而して 此の層序は筆者の調査區域內に見られる標準層序であり，双六階に對比せら れる。 
$\mathbf{M}_{1}$ 带一高瀨川凝灰岩層の下帶をなするので紫蘇輝石安山岩の厚層より なり背科構造の核心部を形成 する。安山岩中に挫まれる凝 灰岩は帶綠灰色にして層理不 鮮明なれども，成層面の力向 に伸びす長さ 2 糎位のンンズ 狀の淡綠色涂石層を多數含有 してねる。此の凝灰岩に伴つ て局部的飞凝灰質砂岩及び凝 灰質小砂々岩が見られる。安 山岩の上限法集塊熔岩多く, 特に奥子澤部落に於ては水蝕 を受けた種々なる安山岩及び 凝灰岩の大小の䃏の間を安山 岩質熔岩が充した如香ものが ある。

\section{$\mathbf{M}_{\mathbf{2}}$ 帶- $\mathbf{M}_{\mathbf{1}}$ 帶の上に不整} 合的に重るもので一般に可成 り厚々基底磕岩を何する。磞 は種々なる安山岩及び綠色凝 灰岩の圓磁乃至角磕（最大直 徑約 $2.5 \mathrm{~m}$ ) で西る。咸結物 山綠色の火山灰万至火山灰質

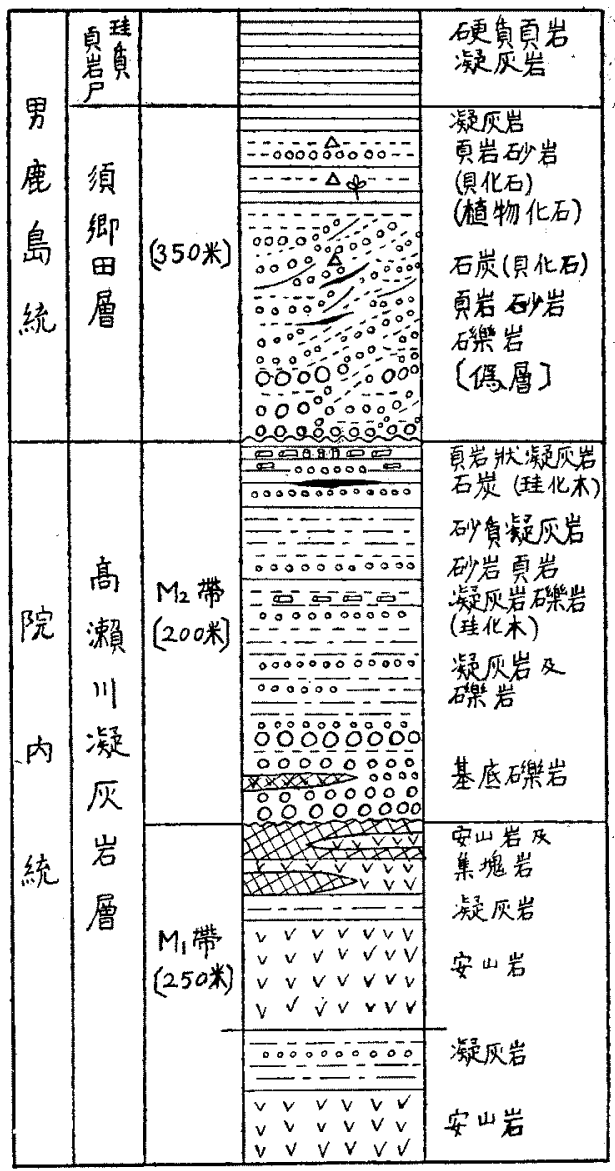

第 1 圖

砂である。合奥ろ澤部落附近に於ては此の基底磁岩中に薄い安山岩質集塊熔

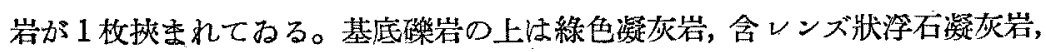
凝灰質小䃏々岩の互層, 中部は凝灰質砂岩, 頁岩が之に加り, 横に倒れた珪 化木及ひ植物破片が多數見出される。次に綠色砂質㠜灰岩層を經て上部は綠 
色頁岩樣凝灰岩が良く發達し，再び横倒しの珪化木及び成層面に直角に埋す れを根を有する珪化木，植物破片，時には厚さ $5 \mathrm{~cm}$ 程度の珪化した石炭層が 存在する。然し化木は調查區域の北方の山地では餎り見掛けられない。

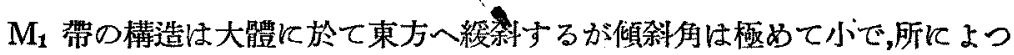
ては緩い波狀裙曲を呈する事もる。南方の沼部落附近では小向心褶曲に依 つて上位の須鄉田層が露出してるる。

$\mathrm{M}_{2}$ 帶こ $\mathrm{M}_{1}$ 帶の關係注奥々澤部落川岸に於て良く見られるが，侵蝕面を

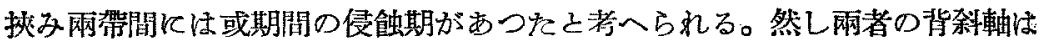
略一致した位置を通つてるる。

$\mathrm{M}_{2}$ 帶の層厚は判定が甚だ困難であるが大約 $200 \mathrm{~m}$ 位と考へられる。又 海成層か非海成層灾は珪化木以外飞化石が牦く不明でする。

須 郷 田 層一-7 萬 5 千分の 1 本薜圖幅に於りる高瀨川凝灰岩層の上部 即ち大塚助教授の須鄉田凝灰質泥質砂岩厤即ち臺島階に相當するもので，此 の帶の中部及び下部は河口堆積物之思はれる砂岩, 砂質頁岩, 頁岩, 硙岩の， 互層よりなり，夥しい㥠層局部的侵蝕面が認められ，時に植物片，炭化木， 厚さ $5 \mathrm{~cm}$ 程度の石炭薄層が見られる。 $\mathrm{M}_{1}$ 帶に比較し全體として遙汃に凝灰

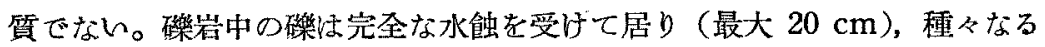
安山岩, 凝灰岩を主とし，又 $\mathrm{M}_{2}$ 帶礫岩中に餘り見受けられない石英粗面岩

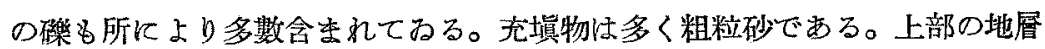
は再び稍々凝灰質之なり，層理不鮮明の風化面灰白色の凝灰質頁岩乃至頁岩 狀凝灰岩多く，中下部に比較し砅岩少く傜層，局部的侵蝕面江全然認められ ない。地層中層理に乏しく粗粒で, 而も風化面が鐵錆色の塊狀砂岩がすり, 時 に石灰質堅硬となり,殆んど常に海棲二枚介，罕介等の化石を含む。此の他海 棲動物化石は凝灰質頁岩, 砂質頁岩中江含有されてるる。此の須鄉田層上 部の含化石層は此の地方に非常に廣く控がつてをり，7萬 5 千分の 1 本莊 圖幅で高瀨川凝灰岩層中に示された動物化石産地の地層法總て此の層位に當 るものと考へられる。含有される化石は大塚助敉授によれば中部中新世のも 
のに相當する。

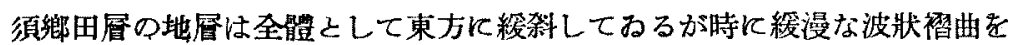
なし, 全詹厚は算定困難であるが大約 $350 \mathrm{~m}$ 前後と考へられる。

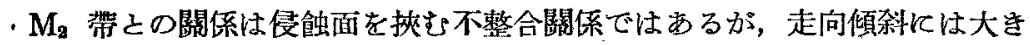
な考無く, 須郷田層に入つて急に河口堆積相になつたと云ふ程度で其の閯に 長以侵蝕期は無かつたと思ふ。。

須郷田層之其の上飞整合的に重る女川階に相當する珪質頁岩層之は高瀨川 以北で活可成り判然之區別し得られるが, 南方に行くにつれて漸移關係之な つてるる。

西 上述した東翼と此較すると大體同樣な岩相及ざ層序關係をるつて 西方へ傾科してるる。異る點を舉げれば， $\mathrm{M}_{1}$ 帶中に摤をれる凝灰岩層の上

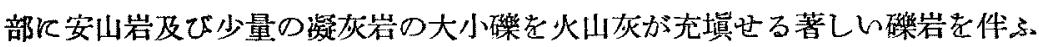
こ己， $\mathbf{M}_{2}$ 帶中に厚い玄武岩質の熔岩及び集塊熔岩の挫委れてねること等で ある。

此の西䔬に於ては高瀨川々岸の鳥田目部落以北に於て $\mathrm{M}_{2}$ 帶中部以下, 南 方金山部落附近で須鄉田層中部をでしか高瀨川凝灰岩㲊は露出せず，西側の 珪筫頁岩層以上の累層之は著しい断層に依つて境されて居る。此の雨者の境 を断層己解釋したのは（7 萬 5 千分の 1 本莊圖幅では整合關係こなつてね る),此の境線に沿つて北方に於て此の地方に廣く撰つたもの之考へられる須 墽田層が缺如L， $\mathrm{M}_{1}$ 帶と思注れる安山岩體或は $\mathrm{M}_{2}$ 帶が珪質頁岩層に直接 接してるること，文玄武岩，石英粗面岩等の夥しい岩脈が並列してわるとと， 西側の珪質頁岩層が（特に烏田目部落以北に於て）强度の禇曲を示してるる

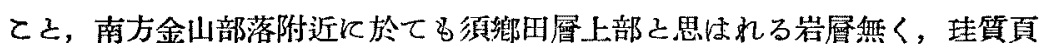

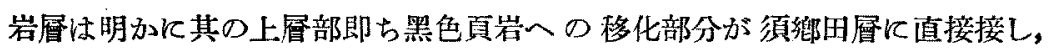
夫も摄亂を受けてるるてと等より考虑したものである。然も烏田目以北々於 て此の境界線飞接する珪質頁岩層は, 茨臺部落束北 $1 \mathrm{~km}$ の山腹の崖及び鳥 田目部落對岸の川岸等に於て明かに觀取されるが, 鋸䔢狀の小刻みな銳角的 
98

片 山

勝

な褔曲をなし，其の軸面は大體東方へ約 40 度僬科し，稀 に小規模であるが緩傾科の東方よりの担上りの斷層面を 件つてるる。此の柏曲狀態上り筆者活此の衒層は或㤬衝 上斷層で，束側の高瀨川㠜灰岩層上りなる地塊が西方の 上位層よりなる地塊に對し押上つてるるのではなからう か己考へてるる。但し此の斷層に依る喰違ひ及び珪質頁 岩層の梖曲度は南方に行く程小となつてをり，又上述の 强度の褶曲をなす珪質頁岩層仙此の斷層線の西侧に沿ぬ。 大體水平距離 $1 \mathrm{~km}$ 輻以內の區域に限られてわる。

以上記述した西方背科の構造を高濑川に沿つた露頭に 依つて模式的に圖示すれば第 2 圖の如くになる。

\section{B. 中 部}

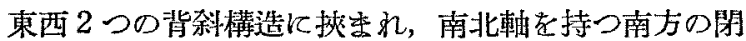
ぢれ 1 向斜構造が發達し，其の爲め珪質頁岩層怯北方上 り細長く南「して露出してるる。向科構造底部は藏部落 附近の玄武岩々脈により一部擾亂されておるが他は極め

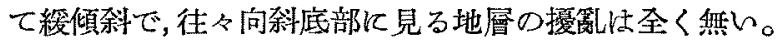

$\mathbf{M}_{\mathbf{2}}$ 带一一老方盆地南方の地域は露出悲く, $\mathbf{M}_{\mathbf{2}}$ 帶下部 の岩質注判然しないが，大部分任磁狀の浮石鿬を多量 に含有し，帶綠灰色にして層理不明の凝灰岩層が主體で あるが，他矤灰質砂岩乃至頁岩も夾在する。凝灰岩中 の浮石碎の大きさは大體 $5 \mathrm{~cm}$ 以下で,一般に西方背斜の $\mathrm{M}_{2}$ 帶中に見るるの上りる大きく角形で，其の量も增加 してるる。上部に至ると安山岩, 凝灰岩, 浮石, 少量の 石英粗面岩の牛圆乃至圓磞 (5 cm 以下) 荻山灰質砂が 充填しそ中磞々岩を挫んでるる。而して上限近くには小 規模乍ら啋層及び局部的削剝面が見られ，又凝灰質頁岩

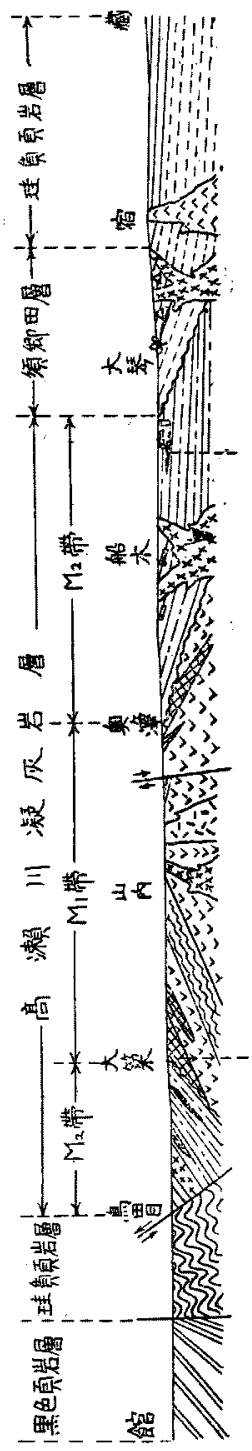

第 2 圆 
中には横倒し或は直立した根を有する珪化木多く, 珪化して石炭薄層も見ら れる。

$\mathrm{M}_{2}$ 帶の分布は地留圖に示した如く老方盆地南方まで〉乫然消隇し，館合 部落東方以北では須郷田層が東方背科の核心部をなす $\mathrm{M}_{1}$ 帶の安山岩上に直 接不整合に重つてわる。即ち此の消滅は $\mathrm{M}_{2}$ 帶自體も多少厚さを減じてねる 栐であるが主として須鄉田層基底の侵蝕によるものである。然し $M_{2}$ 帶の全 層厚は西方背斜に於けると大差無く, 此の消滅の急激に見えるのは地層の傾 科が小さい䉆である。

$M_{2}$ 帶と東方の $M_{1}$ 帶安山岩との閣係注露出不定であるが恐らく西方背斜 に於けるが如き輕度の不整合であらうと考へられる。

須鄉田層——西方背科より東へ移るとつれて頁岩・砂岩は少く礫岩が多 くなり，俅層の發達を見る。又局部的侵蝕も夥しくなり且つ大規模になつて

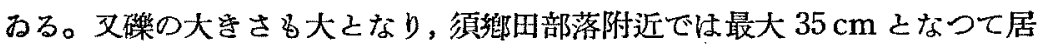
る。

因みに 7 萬 5 千分の 1 本莊圆幅では安山岩質集塊熔岩と水成の大啋々岩とを同 一の「安山岩犋集塊岩」の符號で圆示されてるる。然し筆者の調查區域では高瀨川上

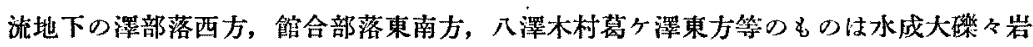
であり，敦机も筆者の須鄉甽層の中のものである。

又此の中部地域に於ては須㰾田層江西部に比較し秒々凝灰質で化石多く, 西部に於て多量の貝化石を含有する鐵錆色含化石塊狀砂岩子存在する。

$\mathbf{M}_{2}$ 帶‘この關係は不整合であるが侵蝕量は西方に小，東方に大となつてね る。即ち兩者の境界を追跡して行く乙地下の澤部落附近をでは大體兩者間に 傾斜走向の大差無く，須郷田層值下の地層8略同層位之考へられるが，地下 の澤以東は急激に侵蝕量が賭大して, 逐に館合部落東方では $\mathbf{M}_{2}$ 帶は全部萷 剥され，須鄉田層が直接不整合的に $M_{1}$ 帶安山岩を覆つてるる。而して東に 移万之共に須鄉田層の層厚は概算須鄉田附近 $200 \mathrm{~m}$, 館合東方 $60 \mathrm{~m}$ 亡急減 してォる。老方部落東方に於ける同層基底磁岩の磁は主として多種の安山岩 大磂（最大 $1.5 \mathrm{~m}$ ) よりなり, 充填物は安山岩の風化により生じ粗粒砂乃 
至小粒である。

珪質頁岩層一一所謂女川層中に見られる風化面白色の硬質頁岩よりなり

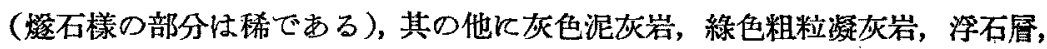
含レンブ狀浮石凝灰岩を抶导所がある。

下位の須鄉田層とは整合漸移關係であるが，老方東方橫菲東線の通する谷 の露頭で珪質頁岩層の一部が下位の薄い須鄉田層を覆蔽して, $\mathbf{M}_{\mathbf{1}}$ 帶安山 岩の上に磁岩質の地若なく直接不整合的に載つてねる。

珪質頁岩層中の化石は稀に少量見出される程度で，海䄸の針骨，魚鱗，鮫 蓄等を層內に散在的に含んでるる外，珪藻，放散蟲等の化石を合有してるる ととがある。

\section{C. 東 部}

以上述へてて來を中に便宜上東方背斜と云ふ言葉を屡々用ひをが，此の東部 地域の地質構造は背科構造とは云へない。即ら西方背科に於ける $\mathrm{M}_{\mathbf{1}}$ 帶の續 き己考へられる安山岩質熔岩及び集塊熔岩が下位に西り，其の上には $\mathrm{M}_{2}$ 帶 と思はれる地㲊なく直接不整合的に化石及び岩質等上り須鄉田層己考へられ る地層が重つて居り，其つ中既に前項で述べ安山岩體が西側のるのは西方 へ，他北方の一部を除き全體として東方へ緩科してぬる。此の須鄉田層の 基盤をなす安山岩體は武道，境雨部落を結ぶ方向の西落ら小断層により繰返 されて，南北方向に長い2 體の露出を見せてるる。

西 側 西側の安山岩體は中間に水成岩層を㣣んで居るが，之は南方では 凝灰質砂質頁岩，頁岩質砂岩，含磼凝灰岩上りなるので植物破片を含むと とがある。北方では主として砂質凝灰岩己浮石小緣をもつ凝灰岩よりなつて 居る。此の凝灰岩層の傾斜より西側の安山岩體恪略西方飞緩拣してるるもの と推察される。合凝灰岩㸴より上部注集塊岩が屡々摤まれて居る。

此の安山岩體東側の須稂田層を鐵道に沿ふ、露頭に就て进ぺる，侵蝕面を 境として安山岩體上に種ふなる安山岩の牛圓万至圓形大磷(最大淔徑 $1.5 \mathrm{~m}$ ) を安山岩風化による粗粒砂が充填した大制基底磁岩が重つてるる。之に續い 


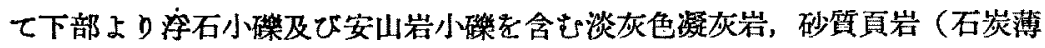
首), 薄い安山岩熔岩 (此の下部の凝灰岩及び熔岩は局部的のもの), 非常に多 量の海椿介化石を含有する特色ある極るて粗粒均質の石灰質堅硬な砂岩が重 つてみる。次いで此の地區の須郷田層主部を形成する層理不鮮明にして淡褐 色の砂岩厚層が重る。此の砂岩下部には數帶の化石帶があり, 又西方背科, 中

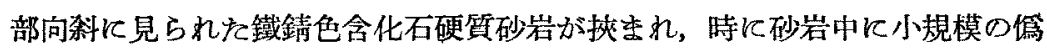

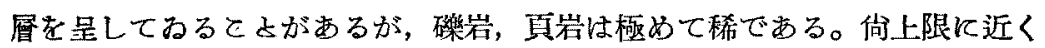
砂岩中に約 $1 \mathrm{~m}$ 幅の炭質微粉を多量飞含む黑色の層, 及び下部に見られると 同樣な特色ある含化石粗粒砂岩薄層が㣣をれてるる。須郷田層の傾斜は極め て緩漫で層厚は判定困難であるが恐らく $150 \mathrm{~m}$ 以下之推定される(てっに上 限としたのは武道境を結ぶ西落小斷層以西に就て云ふっ。

北方八澤木村瀧上部落に於的る須鄉田層基底部は西北へ緩科し，此處の含

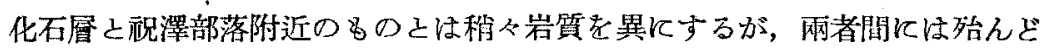
免位上の違ひは無いもの之考へてるる。

此の須郷田層中の化石は大塚助敉授によ札ば西方背科，中部向科の同層中 のるの之同時代と考へられるものである。

東 側 武道，境を結占断層線以東に露出してるる安山岩體は安山岩質集 塊岩が多く，判然とはせ好が熔岩之集塊岩との關係より見て，上に重る單純 な構造の須師田層に比一，小規模の褶曲及び断層により稍々複雜な棈造さな つてるる樣である。故に $\mathrm{M}_{2}$ 帶缺如をも考へ合せ，此の束方地區に於ける $M_{1}$ 帶即ち高瀨川㠜灰器層の下部之須应田層乞の間には, 西方に於ては左程著し くなかつね或程度の地款運動が存在した樣に考へられる。

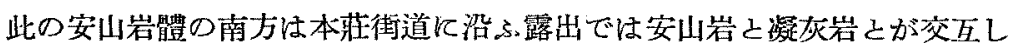
て來るが，露出不足の息其の關係は多くは不明である。此の凝灰岩は層理不 明の琈石小伤磁含有するもので恐らく $\mathrm{M}_{2}$ 帶安山岩て挾有されるものと 思ふ。妇境部落東方の花崗斑岩之其の東の安山岩之の關係も露出不充分で前 者が後者の基盤か否か不明である。 
102

片 山

腅

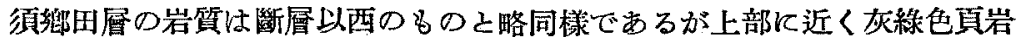

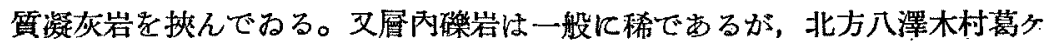
澤束方に南北斷層の西に接して非常に著しい大砂ふ岩の檿層が發達してわ る。但し其の意味は不明である。基底の不整合注鐵道に沿ふ切割で明睹に觀 取され,化石も少量乍ら砂岩中に散在してねる。

須師田㸴の最上限之珪質頁層との關係は南北方向東落ちの小断㸴により切 られてるるが，此の斷層西側に見られる須鄉田層最上部には殆んど珪質頁岩 層こしても差支へ無い岩質の所も无り，兩者は完全な漸移關係にある。

以上各地區に分つて須鄇田層と其の上下層との成層關係に就て述べたが， 既に大塚助敉授が提唱されれ如く，堆積輪廷より考へれ場合須鄉田層は高瀬

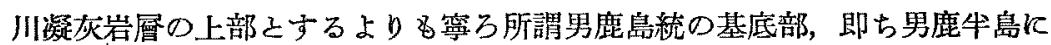
於ける臺島階に對比し得る地層之考へ， $\mathrm{M}_{2}$ 帶以下の高濑川㠜灰岩層が双六 階に當る地層こ考へるのが適當である。此の對比は大塚助教授によれば古生 物學的にも亦適當なものである。

南北斷層以東の珪質頁岩層は大體單純な單科構造で東力乃至東南方に緩斜 してるる。南方大澤部落附近の黑色頁岩としたものは, 珪質頁岩層之漸移關 係にあり，模式的な黑色頁岩をは大分岩質を異にし寧ろ珠質頁岩に近く，稜 角西る緇片に風化分解するここなく, 塊狀にして稍々泥質で風化面は白色乃 至灰白色，珪藻の化石を舍有する。

以上述べた此の東部地區の構造を橫莊東線に沿ふ露出に依り模式的に圖示 すれば第 3 圖の如くになる。

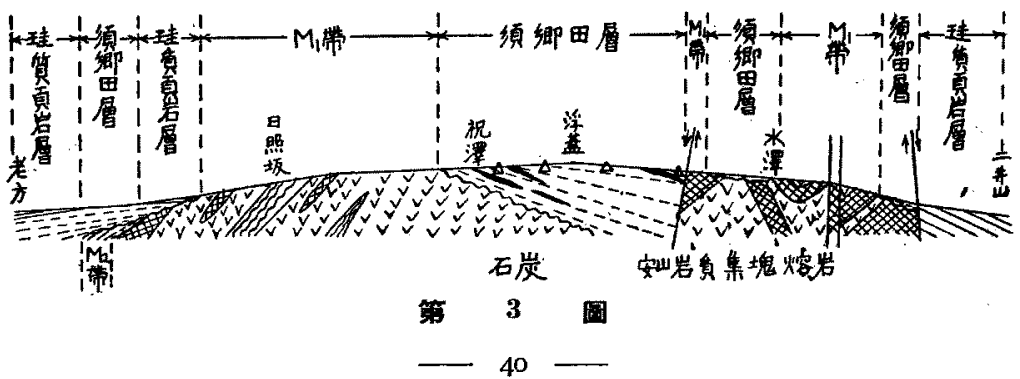




\section{IV. 要 䄪}

以上記速した所を要約すれば次の数項となる。

1）調查地域內の地層け高瀨川凝灰岩層及び須鄉田層が主體となり，其の 東西兩限に於て西は東方よりの衙上斷層かと思注れる大斷層に上り, 東は東 落ら小斷層により夫く珪質頁岩以上の累層乙境を接してるる。

2）双六階に對比し得る高瀨川凝灰岩層及び臺島階に對比される須的田層

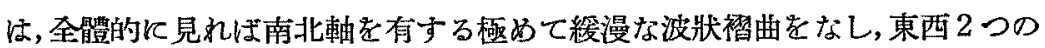
背科と中央向斜が認められ，向科底部に猡鄉田層之整合關係に西る女川階 の珪質頁岩層が發達してるる。

3）高濑川凝灰岩層は岩質，及び成層關䋆から $\mathrm{M}_{1} ・ \mathrm{M}_{2}$ の2 帶に區分さ れ得る。 $\mathrm{M}_{\mathbf{1}}$ 帶注凝灰岩を摤む安山岩質熔岩及び集塊岩類である。帶は主之 して凝灰質岩石よりなり，中上部には一般に多量の珪化木を含有する。

４4）須郷田層は最上限を除き比較的凝灰質ならざる地層よりなり，多量の 海棲動物化石を有し夫によつて中部中新世こ推定される。

5）西方背科及び中央向斜西牛に於ては $\mathrm{M}_{2} ・ \mathrm{M}_{2}$ 兩帶及び須郷田層は夫々 輤微な不整合關係にあり，走向傾斜には大差が無い。而して須鄉田層は夥し

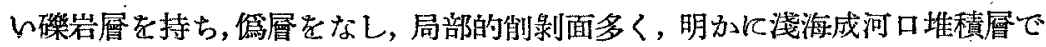
ある。

6）中央向科東牛に於ては須鄉田層基底の侵獊量が急激に堌加し，北部で は $\mathrm{M}_{2}$ 帶は侵蝕され盡し，薄くなつた須郷田層が直接 $\mathrm{M}_{\mathbf{1}}$ 帶上に不整合的に 重つてねる。又珪質頁竖層が一部須郷田層を覆蔽して $\mathrm{M}_{1}$ 帶に直接接してね る所がある。份 $\mathrm{M}_{2}$ 帶は東方に行くに從ひ其の含有する浮石小㗜の大き・ 量を貹加する傾向を持つ。

7）東方背斜地區に於ては中央を南北に走る西落ち小斷層により $\mathrm{M}_{\mathbf{1}}$ 帶が 繰返して再度露出して居り， $\mathbf{M}_{2}$ 帶注全然無く,須鄉田層が不整合を以て $\mathbf{M}_{\mathbf{1}}$ 帶を薄く覆つて東方に縉斜してある。 $M_{1}$ 帶，特に東方に露出する $M_{1}$ 帶は 須鄉田層に比べ稍々複雜なる構造を有 $\mathrm{L}, \mathrm{M}_{1}$ •須鄉田兩層間に或程度の地殸 
運動の存在した事を思はしめる。尚此の地區の須鄉田首は西方の同層に見る

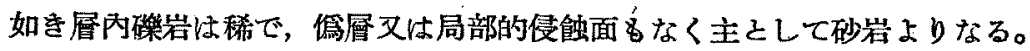

7）而して須鄉田層は 7 萬 5 千分の 1 本莊圖幅に於りる高瀨川㠜灰岩庴 の上部を指するのであるが，化石及び成首關係より男鹿牛島の臺島階に相當 するもので, 双六階に對比される下位の高瀨川凝灰岩層より切離して考へる のが適當である。

份探藮せられたる化石を一括し表訅すれば次の如くである。(探集地點番號は地算

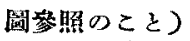

\section{343}

Chlamys araksawai Nom.

Pecten kimurai Yok.

Venericardia feruginosa A. AdAms

Pecten sp.

Panope japonica.

Crepidula sp.

Panomya simotomensis OTUKA

Phalium yabei Nomura et HataI

M 85

Balanus sp.

Cardiuus sp.

M 232

Pecten tokyoensis kimurai YoK.

Pecten kagamiarus subsp.

Venevicardia feruginosa A. ADAms

Tachyhrynchus? $s p$.

Thracia hitosaoensis NomurA

Taras feruginata HAT.

Dentdalium katayamai OTUKA

Mosculis sp.

Turitella sp.

M 233

Pecten kimurai tokyoensts YoK.

\section{Cardium sinzieuse}

Venericardia feruginosa A. AdAMS

Dosinea kaneharai Yok.

Panope japonica

Panomya simotomensis OTUKA

Suruculites $s p$.

Opsephia yokoyamai KANEIIARA

Dentaliuen sp.

M 64

Pholadomya katayamai OtukA

Cardium sp.

Dentalium sp.

Brachiopoda.

M $\mathbf{3 1 0}$

Pecten tokyoensis kimurai YoK.

Pecten paraprebjus Nomura and Hatai

Venericardia fernginosa A. Adams

Coptiphyris grayi Davidson

Terebradnla tenuis Hayasaka

M 191

Pecten protomollitus Nomura.

Pecten arakawai NomurA

Pecten katayamai OTukA 
Venericardia feruginosa A. ADAMs

Phalium yabai Nomura and HataI

Coptiphris grayi DAvioson

Panope japonica

Amalthea sp.

Dantalium sp.

Glycymeris sp.

Dosinea pg.

Crepidula sp.
M 203

Pecten protomolites NomURA

Coptiphris grayi Davidson

Diodra katayamai OTukA

M 199

Caryptica tubura OTUKA

Cardium sp.

Gastropoda 
本莊・横手間第三紀曆地質圆

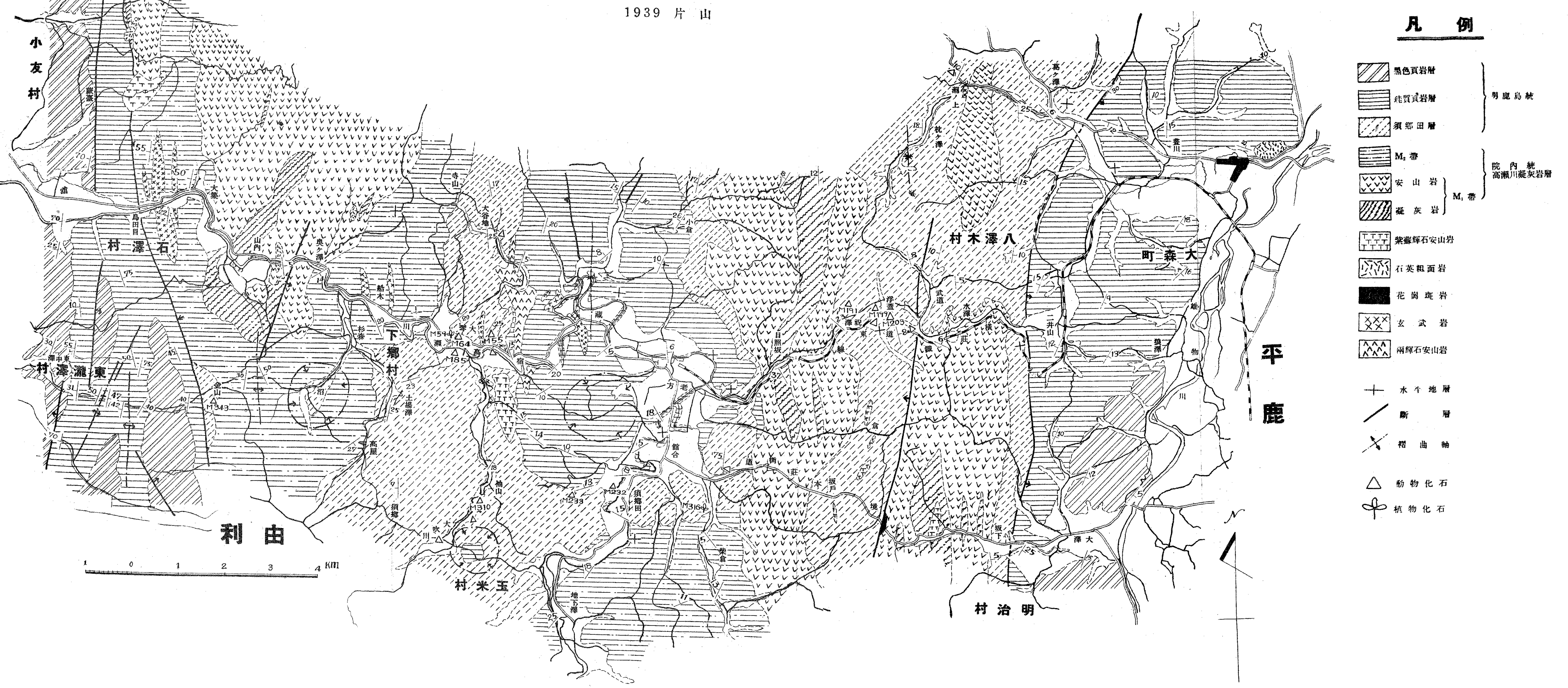

